Pamiętnik Literacki 2017, 3, s. 101-119
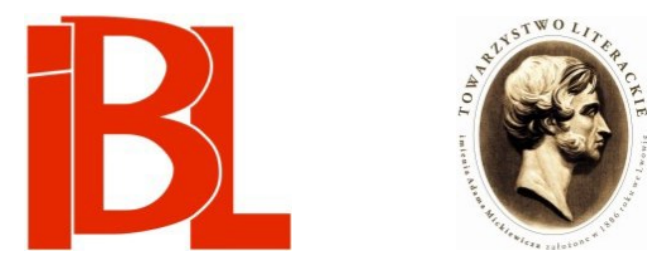

\title{
Renesansowe teorie figuratywności (II) : Jakub Górski
}

\author{
Wojciech Ryczek
}




\section{Z A G A D N E N I J E Z Y K A A R T Y T Y C Z N E G O}

Pamiętnik Literacki CVIII, 2017, z. 3, PL ISSN 0031-0514

DOI: $10.18318 / \mathrm{pl} .2017 .3 .6$

WOJCIECH RYCZEK Uniwersytet Jagielloński, Kraków

\section{RENESANSOWE TEORIE FIGURATYWNOŚCI (II): JAKUB GÓRSKI*}

Na karcie tytułowej podręcznika Jakuba Górskiego (1525 - 17 VI 1585) do elokucji De figuris tum grammaticis, tum rhetoricis (O figurach gramatycznych i retorycznych, 1560), który należał do liczącego około dwóch tysięcy tomów księgozbioru Jana Brożka (1585-1652), matematyka, astronoma, bibliofila, profesora i mecenasa Akademii Krakowskiej, znajduje się odręczna notka, skreślona ręką właściciela. W przekładzie brzmi ona następująco: „Kiedy Adrian Romanus przebywał w Krakowie, prosił mnie, abym odnalazł dla jego syna Jakuba książkę Jakuba Górskiego o figurach, co uczyniłem. Bardzo chwalił tego autora" ${ }^{1}$. Trzeba przypomnieć, że Adriaan van Roomen (1561-1615), wybitny flamandzki matematyk, zatrzymywał się w Krakowie podczas podróży z Würzburga do Zamościa, gdzie prowadził wykłady $\mathrm{z}$ algebry i geometrii w Akademii założonej przez Jana Zamoyskiego (1594) i udzielał prywatnych lekcji synowi kanclerza, Tomaszowi. Pobyty w polskiej metropolii były dla humanisty okazją do studiów w bibliotece uczelni oraz do spotkań z jej profesorami. W takich okolicznościach doszło do zawarcia znajomości z Janem Brożkiem ${ }^{2}$, która zaowocowała dyskusją na temat figur izoperymetrycznych ${ }^{3}$. Prośba flamandzkiego uczonego, odnotowana skrupulatnie przez Kurzelowite, nie

* Publikacja powstała w ramach grantu naukowego Politropia: wczesnonowożytne teorie i koncepcje figuratywności, finansowanego ze środków Narodowego Centrum Nauki przyznanych na podstawie decyzji numer DEC-2013/11/D/HS2/04529. W trakcie pracy nad niniejszym tekstem autor był stypendystą Fundacji na rzecz Nauki Polskiej (program START 2015). Pierwsza część Renesansowych teorii figuratywności ukazała się w z. 3 „Pamiętnika Literackiego” z 2013 roku.

1 Notkę na karcie tytułowej zawiera podręcznik oznaczony sygnaturą BJ Cim. 325: „Adrianus Romanus, cum esset Cracovia petit a me, ut pro eius filio Jacobo conquirerem librum Jacobi Gorscii de figuris, quod feci. Magni faciebat hunc authorem”. Przekład tej notki oraz wszystkie pozostałe sa, o ile nie zaznaczono inaczej, mojego autorstwa. Zob. też J. Za th ey, A. Le w i c ka - Ka mińs ka, L. Hajd uki ewicz, Historia Biblioteki Jagiellońskiej. Red. I. Za r ę bs ki. T. 1: 1364-1775. Kraków 1966, s. 175 (skrócona adnotacja J. Brożka).

2 Według ustaleń H. B a r y c z a (Historia Uniwersytetu Jagiellońskiego w epoce humanizmu. Kraków 1935, s. 728) J. Brożek oprowadzał A. Romanusa po bibliotece Kolegium Większego podczas pierwszego pobytu uczonego w Krakowie, 26 III 1611.

3 I. Broscius, Epistolae ad naturam ordinatarum figurarum plenius intelligendam pertinentes. Cracoviae 1615. Zob. też P. P. B o c k s t a e le, Adrianus Romanus and Giovanni Camillo Gliorioso on Isoperimetric Figures. W zb.: Mathematical Perspectives: Essays on Mathematics and Its Historical Development. Ed. J. W. D a u b e n. New York 1981, s. 5-6. 
miała jednak nic wspólnego z zainteresowaniami obu humanistów problemami geometrii Euklidesowej. Dotyczyła wprawdzie figur, lecz nie tych zakreślanych $\mathrm{w}$ przestrzeni za pomoca cyrkla i liniału, ale tych łączonych $\mathrm{z}$ formami wysłowienia.

Książka, o którą Romanus poprosił Brożka, była $z$ pewnością pomocna dla Jakuba van Roomena ${ }^{4}$, syna matematyka, w nauce retoryki. Stanowiła bowiem uporządkowane kompendium wiedzy o ozdobach mowy, uzupełnione wypisami z dzieł najlepszych autorów (głównie Cycerona i Wergiliusza). W ujęciu Kazimierza Morawskiego, badacza życia i twórczości Górskiego, pierwszy okres działalności naukowo-dydaktycznej humanisty przypadł na lata 1554-15635. Rozpoczął się wraz z wykładami na temat dialogu Cycerona $O$ mówcy, wygłoszonymi w Akademii Krakowskiej (na wydziale Artium) w semestrze zimowym 1554/1555 roku, zakończył się zaś wraz z opublikowaniem podręcznika dialektyki (Commentariorum artis dialecticae libri decem, 1563) ${ }^{6}$. W tym czasie, wypełnionym wieloma zajęciami akademickimi, Górski opracował trzy podręczniki związane ze sztuką retoryczną, które ukazywały się rok po roku w oficynie wydawniczej Mateusza Siebeneichera: De periodis atque numeris oratoriis (O okresach i klauzulach retorycznych $\langle 1558\rangle$, dedykowany Piotrowi Myszkowskiemu, kanonikowi krakowskiemu i gnieźnieńskie$\mathrm{mu})^{7}$, O rodzajach wymowy (De generibus dicendi $\langle 1559\rangle$, dedykowany Filipowi Padniewskiemu, podkanclerzemu koronnemu $)^{8}$ oraz - wspomniany już - De figuris tum grammaticis, tum rhetoricis (dedykowany Janowi Łowczowskiemu, opatowi klasztoru benedyktynów w Tyńcu $)^{9}$. W pierwszym podręczniku humanista przedstawił reguły tworzenia harmonijnie zestrojonych okresów i klauzul retorycznych, w drugim omówił rozmaite rodzaje (style) wymowy (np. sofistyczny, filozoficzny, poetycki, historyczny), a w trzecim sporządził katalog tropów i ozdób językowych.

Jakub van Ro om en (zm. 1635) był najstarszym synem Romanusa i Katarzyny Trauthmann. Został doktorem medycyny w Lowanium. W roku 1623 spotkał się z Brożkiem w Padwie i przekazał mu, być może w podziękowaniu za podręcznik Górskiego, traktat ojca, Canon triangulorum sphaericorum [...] (Moguntiae 1609).

5 K. Moraws ki, Jakub Górski. Jego życie i dzieła. Kraków 1892, s. 6. Zob. też W. Ma dy da, Jakub Górski, filolog-humanista w Akademii Krakowskiej w XVI wieku. „Meander” 1964, nr 11. W. F. M u r a w i e c, Jakub Górski (ok. 1525 - 1585). W zb.: Złota księga Papieskiej Akademii Teologicznej. Red. S. Pie c h. Kraków 2000.

6 Zob. S. Zi e m s ki, Jakub Górski jako logik i myśliciel. „Studia Filozoficzne” 1962, z. 2.

7 Na karcie tytułowej zamieszczono również wykaz autorów, $\mathrm{z}$ których dzieł korzystał Górski w trakcie pracy nad wykładem nauki o okresach i klauzulach retorycznych (Cyceron, Kwintylian, J. Sturm, J.-L. d'Estrebay, M. A. Maioragio). Druga edycja podręcznika przygotowana przez J. Wi i lo gó órs ki e go ukazała się w 1575 roku.

8 Edycja współczesna: J. Górski, De generibus dicendi / O rodzajach wymowy. Wyd., przeł. R. S awa. Red. nauk. A. Axer. Warszawa 2010. Sprostowania wymaga błędna interpretacja łacińskiego epicedium Naenia funebris (Naenia żałobna, Cracoviae 1586) autorstwa Sz. Szy m on o w i c a. Młody poeta napisał ten utwór żałobny po śmierci Górskiego (17 VI 1585) jako konsolację dla swego nauczyciela i mistrza, S. Sokołowskiego, ucznia i przyjaciela zmarłego. Mianem „drugiego Grzegorza z Nazjanzu” („alter Nazianzenus”) określa Simonides (w. 235) nie Górskiego, jak twierdzi autor wstępu (ibidem, s. 16), ale Sokołowskiego, stawiając go na równi z Nazjanzeńczykiem, przeżywającym smutek po śmierci przyjaciela, Bazylego Wielkiego. Zob. W. Ry c ze k, Rhetorica christiana. Teoria wymowy kościelnej Stanisława Sokołowskiego. Kraków 2011, s. 298-301.

9 J. G or s ciu s, De figuris, tum grammaticis, tum rhetoricis libri quinque, nunc recens aediti. Cracoviae 1560. Dalej odnotowuję tylko odpowiednie stronice. 
Anna Werpachowska, analizując głośną w polskich kręgach humanistycznych polemikę Górskiego z Benedyktem Herbestem (ok. 1531 - 1598) na temat periodu retorycznego w teorii i praktyce oratorskiej Cycerona, upatrywała w rozdzieleniu problematyki dialektycznej (logicznej) od zagadnień sztuki wymowy, pojawiającym się w podręczniku krakowskiego wykładowcy, śladów inspirowania się koncepcjami Piotra Ramusa ${ }^{10}$. Problem jednak w tym, że podobną tendencję odnajdujemy w pismach innych humanistów, takich jak Rudolf Agricola, Philipp Melanchton czy Johann Sturm. Każdy z nich zgłaszał postulat wyraźnego określenia kompetencji trzech sztuk „trywialnych” (gramatyki, retoryki i dialektyki, logiki), a następnie podejmował próbe jego realizacji w wykładach, które ukazywały się później w postaci podręczników. Górski bez wattpienia znał dzieła logiczne Ramusa, czemu wyraz dał w liście do „młodzieńców studiujących sztukę dialektyczną”, zamieszczonym w przywołanym traktacie dialektyki $z 1563$ roku $^{11}$. Nazwisko francuskiego uczonego pojawia się tu w doborowym towarzystwie znanych humanistów: Jerzego z Trapezuntu, Agricoli, Joachima Périona, Sturma, Bartolommea Viottiego, Jodoka Willicha, Johanna Caesariusa, Celia Curionego i Melanchtona ${ }^{12}$. Jeśli jednak poszukiwać inspiracji ramistycznych w retoryce Górskiego, to najwyraźniej można je dostrzec, jak sądzę, w myśleniu o wymowie jako o elokucji i pronuncjacji, czyli sztuce ozdabiania słów. Wszystkie trzy podręczniki humanisty dotyczą zagadnień właściwych dla retorycznej nauki o stylu i języku (okresy i klauzule oratorskie, rodzaje i podrodzaje wymowy, tropy i ozdoby jezzykowe). Nie należy jednak zapominać, że retoryka została ograniczona przez Ramusa do umiejętności ozdabiania i wygłaszania mowy na potrzeby edukacji szkolnej ${ }^{13}$. $Z$ regułami inwencji i dyspozycji uczeń zapoznawał się szczegółowo podczas wykładów $z$ dialektyki. Otrzymywał w ten sposób pełną wiedzę na temat zasad tworzenia pięknej (ozdobnej) i przekonującej mowy.

Ożywione zainteresowanie sztuką wymowy we wczesnonowożytnej Europie zaowocowało z czasem podręcznikami poświęconymi wyłącznie figurom retorycznym. Do najważniejszych należały dzieła takich humanistów, jak Antonio Mancinelli (Carmen de figuris, 1489), Jean Despautère (De figuris, 1512), Peter Schade (Mosellanus) (Tabulae de schematibus et tropis, 1516) ${ }^{14}$, Johannes Reusch (De tropis

A. W e r p a c how s ka, Z dziejów retoryki XVI wieku. Polemika Jakuba Górskiego z Benedyktem Herbestem. Wrocław 1987, s. 14. Zob. też tej autorki Problem interpunkcji $w$ teoriach retorycznych Jakuba Górskiego i Benedykta Herbesta. „Pamiętnik Literacki” 1980, z. 4.

11 Warto wspomnieć w tym miejscu o interesującym śladzie angielskiej recepcji podręcznika Górskiego do dialektyki. Powoływał się bowiem na niego J. Rain olds (Oxford Lectures on Aristotle's „Rhetoric”. Ed., transl., comment. L. D. Gre en. Newark, Del., 1986, s. 107, 167, 171, 183) podczas wykładów na temat Retoryki Arystotelesa, wygłaszanych w Oksfordzie (Corpus Christi College) w latach 1572-1578.

12 Zob. J. G or s c i u s, Commentariorum artis dialecticae libri decem. Lipsiae 1563, s. 22-23. Porządek tego wyliczenia nie jest bez znaczenia. Górski wymienia na początku Arystotelesa i Cycerona, dwóch „najlepszych mistrzów rozprawiania”, następnie nauczycieli, a na końcu „znakomitych pomocników" (do tego grona zalicza Ramusa).

13 Zob. P. Mack, Ramus and Ramism: Rhetoric and Dialectic. W zb.: Ramus, Pedagogy, and the Liberal Arts. Ramism in Britain and the Wider World. Ed. E. A. Wils o n, S. J. Reid. Farnham 2011, s. 8.

14 Zob. Ry c z e k, Renesansowe teorie figuratywności: Peter Schade (Mosellanus). „Pamiętnik Literacki” 2013, z. 3. 
orationis et dictionis, 1521), Johannes Susenbrotus (Epitome troporum et schematum, $1540)^{15}$. Rozprawa Górskiego o figurach wpisuje się zatem w humanistyczną dyskusję nad istota, formą, funkcjami i sposobami nauczania wymowy. Trzeba ponadto wyraźnie zaznaczyć, że wyróżnia się spośród wszystkich podręczników retorycznych, które powstały na ziemiach dawnej Rzeczypospolitej, ponieważ jest w całości poświęcona problematyce szeroko rozumianej ozdobności językowo-stylistycznej. Zagadnienia te rozpatruje Górski konsekwentnie, podobnie jak we wcześniejszych dziełach, w perspektywie przepisów dotyczących naśladowania stylu (retoryki) Cycerona ${ }^{16}$.

W tytule trzeciego ze swych podręczników nawiązał humanista do podstawowego podziału form językowych, który przeprowadził Kwintylian (figury gramatyczne i retoryczne). W wykładzie zasad ich tworzenia wykorzystał Górski również inne znane w teorii retoryki rozróżnienie: na figury słów (przekształcenia językowe) i myśli (przekształcenia semantyczne), wyjaśnione szczegółowo przez Cycerona w dialogu O mówcy (III 52, 200). Kompendium Górskiego składa się z pięciu ksiag. W pierwszej omawia on figury gramatyczne (ortograficzne i syntaktyczne, które można podzielić dodatkowo na cztery grupy); w drugiej - tropy (główne formy tropiczne wraz z ich odmianami); w trzeciej - figury słów (np. epitet, hendiadys, asyndeton, klimaks, palilogia, diafora, wykrzyknienie, pytanie retoryczne, zamilknięcie); w czwartej - figury myśli (np. enumeracja, podział, dystrybucja, sentencja, parezja, exemplum, figury związane z poruszaniem odbiorcy i wyrażaniem uczuć, patopeja, podobieństwo, parabola, porównanie); w piątej - inne figury myśli, pomijane przez niektórych retorów (rodzaje dygresji mające swój udział w amplifikacji, prozopopeja, pragmatografia, topografia, chronografia). $Z$ wykazu figur opisanych we wspomnianych księgach zamieszczonego na końcu podręcznika wynika, że Górski uwzględnił 246 rozmaitych form wysłowienia. Każda z nich otrzymała krótką definicję oraz została opatrzona przykładami z mów Cycerona i dzieł Wergiliusza. Oprócz wyjaśnienia istoty danej figury niekiedy pojawiaja się rozważania Górskiego poświęcone analizie kwestii szczegółowych (np. błędów popełnianych podczas tworzenia metafory, rozmyślań Arystotelesa na temat onomatopei, różnic między pominięciem a zamilknięciem).

Nie ulega watpliwości, że swoistym rysem wszystkich trzech podręczników Górskiego jest „formalistyka retoryczna” (określenie Kazimierza Morawskiego ${ }^{17}$ ), która prędzej czy późnej sprowadza na czytelnika znużenie. Chociaż wiele z dystynkcji terminologicznych może wydawać się jałowymi, trzeba pamiętać, że kompendia te miały w zamyśle autora charakter techniczny i instruktażowy. Zrodziła je potrzeba zapoznania uczniów z przystępnym wykładem reguł poprawnej, zrytmizowanej i ozdobnej łaciny. Odtwarzając tropologię (naukę o tropach) Górskiego,

Zob. P. Ma ck, A History of Renaissance Rhetoric 1380-1620. Oxford 2011, rozdz. 10: Manuals of Tropes and Figures. Zob. też S. A d a m s o n, G. Al ex a n d e r, K. E t t e n h u b e r, Introduction: the figures in Renaissance theory and practice. W zb.: Renaissance Figures of Speech. Ed. ... Cambridge 2007.

16 Zob. Z. Ry ndu ch, Nauka o stylach $w$ retorykach polskich XVII wieku. Gdańsk 1967, s. 24-25. - B. O tw in ow s k a, Cyceronianizm polski. W zb.: Literatura staropolska i jej zwiazki europejskie. Red. J. Pelc. Warszawa 1973, s. 107. 
wyłożoną w drugiej księdze rozprawy, wskażę jej źródła i główne obszary swoistości. Najpierw zrekonstruuje poglądy humanisty na funkcję wymowy (a zwłaszcza elokucji) oraz na związki retoryki $z$ filozofią. Przedstawię także definicje dwóch pojęć kluczowych dla problematyki ozdób retorycznych (figura, trop), a następnie opiszę poszczególne tropy i ich odmiany (alegoria, ironia).

W liście dedykacyjnym skierowanym do Jana Łowczowskiego herbu Gryf, opata klasztoru benedyktynów w Tyńcu (1558-1568), mecenasa Akademii Krakowskiej i fundatora szkoły przyklasztornej, pojawiaja się toposy znane z dwóch wcześniejszych podręczników Górskiego. Pierwszą część dedykacji wypełniają wobec tego rozważania nad znaczeniem sztuki retoryki w życiu społeczno-politycznym, osnute wokół wywodów Marka Brutusa o koniecznym związku między wymową a mądrością, utrwalonych w znanym dialogu Cycerona Brutus, czyli o sławnych mówcach (Brut. 23):

Nemo enim, ut idem sentit, dicere bene potest, nisi qui prudenter intelligit, nemo prudenter intelligit, nisi qui graviter, qui copiose, qui splendide et ad rem praesentem accommodate dicit. Coniuncta etenim haec sunt, alterum sine altero non potest commode suum officium praestare, eloquentia ubertatem ingenii, ingenium lumen eloquentiae postulat. Neque prudentia inops dicendi magnum quid et laude dignum parere, neque eloquentia a prudentia aliena, utilis et laude digna haberi potest. Pernicosa est imprudens copia dicendi, inutilis prudentia infans et indiserta, praeclare igitur Brutus prudentiam eloquentem, eloquentiam prudentem vult esse [Nikt bowiem nie może, jak uważa 〈Brutus〉, dobrze przemawiać, jak tylko ten, kto mądrze myśli, nikt zaś mądrze nie myśli, jak tylko ten, kto przemawia poważnie, obficie, zrozumiale i stosownie do omawianego tematu. Te dwie rzeczy są zatem ze sobą połączone i jedna bez drugiej nie może spełnić dobrze swej powinności, wymowa wymaga płodności umysłu, umysł - światła wymowy. A mądrość uboga w wymowę nie może osiagnąć czegoś wielkiego i godnego sławy ani wymowa odłączona od mądrości nie może osiagnnąć pożytecznej i godnej sławy rzeczy. Nierozumna sztuka przemawiania jest szkodliwa, a nieużyteczna mądrość - niema i niewymowna, dlatego Brutus słusznie chciał, aby mądrość była wymowna, a wymowa - mądra]. [k. A3-A3v]

Istotę retoryki stanowi w przekonaniu Brutusa, podzielanym przez Cycerona i rzeszę renesansowych naśladowców stylu Arpinaty, z Górskim na czele, zasób słów i rozmaitych ozdób językowych (copia verborum). Ujmując rzecz nieco inaczej, cała wymowa sprowadza się tu do dwóch powiązanych ze sobą wieloma „miejscami wspólnymi” umiejętności: amplifikacji (sztuki powiększania materiału językowego) i figuratywności (sztuki tworzenia tropów i figur retorycznych). Mądrość łączy się natomiast $z$ „poznaniem ważnych rzeczy” (rerum magnarum cognitio) i dlatego nie może być automatycznie utożsamiana $z$ abstrakcyjnymi spekulacjami filozoficznymi czy teologicznymi. Obejmuje wiedzę o Bogu, człowieku, otaczającym świecie i zasadach dobrego (uczciwego) życia. Tak rozumianą mądrością praktyczną (prudentia) rządzi poza tym wysoko ceniona przez humanistów filozofia moralna, której zainteresowania koncentrują się przede wszystkim wokół wzorców osobowych i sposobów wartościowego etycznie postępowania, ilustrowanych przykładami zaczerpniętymi $z$ dzieł historyków, poetów i myślicieli.

Słowa Brutusa przywołane przez Górskiego odsyłają do znacznie bardziej skomplikowanego problemu, który został po raz pierwszy postawiony w dyskusjach Sokratesa, Platona i Arystotelesa z sofistami. Chodzi mianowicie o określenie relacji między retoryką a filozofią (mądrością, dialektyką). Dzięki bowiem ożywionej działalności wędrownych nauczycieli wymowy (miłośników pięknego i często nazbyt ozdobnego sposobu wypowiadania się) i filozofów rozprawiających o bezinteresow- 
ności poznania (miłośników „prawdziwej” mądrości) różnice w traktowaniu przez nich języka stały się szczególnie wyraźne. Co ciekawe, formuła Brutusa (mądrość wymowna i wymowa mądra), służąca do opisu idealnej relacji między wymową a filozofią, jest figura retoryczna znana jako chiazm (symetryczne odwrócenie porządku słów). Określa pewien mechanizm zabezpieczający, który ma uchronić retorykę przed przekształceniem się w sofistykę (sztukę posługiwania się wyszukanymi ozdobami językowymi). W świetle sentencji rzymskiego oratora sztuka pięknego mówienia okazuje się nierozerwalnie związana $z$ mądrością. Trop ich retorycznego pojednania (za pomocą figury chiazmu) podjął również Górski, wykładając studentom Akademii Krakowskiej reguły elokucji.

Skoro retoryka została u Arpinaty trwale zespolona $z$ filozofią, to obie dziedziny wiedzy powinny być nauczane $z$ jednakowym zaangażowaniem nauczycieli i uczniów. Tylko wtedy możliwe będzie osiągnięcie ideału zasygnalizowanego przez Brutusa:

Qui certe, si verum agnoscerent, non studia bonarum litterarum, non artes honestissimas, sed suum errorem, suos praeceptores, quorum consilio operam et impensam perdiderunt, accusarent. Dum enim altero studio delectantur eoque contenti sunt, alterum contemnunt, operae suae praetium facere non possunt, neque ea commoda, eos fructos, quae studia litterarum pariunt, assequuntur. A qua calamitate alieni prorsus sunt, qui recto iudicio usi, ita studia sua constituunt, ut neque indiserta rerum magnarum cognitione, neque sola futili et imprudenti copia dicendi contenti esse volunt; verum cognitionem et prudentiam cum eloquentia coniungunt efficiuntque et eloquentiam gravem et sapientem et sapientiam disertam et copiosam $\left[\mathrm{Ci}\right.$, bez wątpienia, jeśli poznają prawdę, skrytykują nie studia bonae litterae ${ }^{18}$ ani najszlachetniejsze sztuki, lecz swój błąd i swoich nauczycieli, za których radą stracili czas i pracę ${ }^{19}$. Jeśli bowiem będą zachwycać się jedną nauką i będą w niej gorliwi, a odrzucą drugą, to nie będą mogli dokonać czegoś ważnego ani nie osiagną tych pożytków i korzyści, które dają studia uczące pisać i mówić. Od tej niedoskonałości są bardzo daleko ci, którzy używając zdrowego sądu, tworzą w ten sposób swe studia, że nie chcą być gorliwi ani w niewymownym poznaniu wielkich rzeczy, ani w daremnej i niemądrej sztuce przemawiania; łączą poznanie prawdy i mądrość z wymową i otrzymują wymowę poważną i mądrą oraz mądrość wymowną i zasobną w słowa]. [k. A5v-A6]

Z prostego stwierdzenia o koniecznym związku między wymową a filozofią (mądrością) wyprowadza Górski projekt edukacji humanistycznej, oparty na pilnym i uważnym studiowaniu zarówno przepisów elokucji, jak i dzieł filozoficznych. Dzięki retoryce uczeń nabywa umiejętności posługiwania się słowem w zakresie amplifikacji oraz figuratywności i dlatego potrafi - w zależności od tematu oraz celu perswazji - tworzyć i pomnażać różne formy językowe. Podczas zajęć z dialektyki i filozofii poznaje natomiast sztukę rozumowania, a także rozprawiania o przedłożonej rzeczy za pomocą kategorii i narzędzi logicznych. Zaopatrzony w podstawową

Określenie „bonae litterae”, upowszechnione w dyskursie humanistycznym przez Erazma z Rotterdamu, niezwykle trudne w przekładzie na język polski, oznaczało studia nad wartościowymi - epistemicznie i etycznie - dziełami starożytnych autorów. Zob. M. C y t o w s k a, Erazmianizm $w$ literaturze polskiej XVI i XVII wieku. W zb.: Studia porównawcze o literaturze staropolskiej. Red. T. Michałowska, J. Ślaski. Wrocław 1980, s. 9-11. - J. D o mański, Erazm i filozofia. Studium o koncepcji filozofii Erazma z Rotterdamu. Warszawa 2001, s. 155-162.

19 Użyty przez Górskiego zwrot („operam et impensam perdere”) jest przysłowiowy. W tej formie językowej pojawia się w dziele Makrobi u s za Saturnalia (II 29-30), gdzie kruk zwraca się do cesarza słowami: „opera et impensa periit”. Najczęściej występuje jednak w postaci „oleum et operam perdere" - 'marnować trud i olej', czyli podejmować próżny, daremny wysiłek. Wyrażeniu temu odpowiada znaczeniowo polskie powiedzenie „szkoda czasu i atłasu”. 
wiedzę o języku (verba - przedmiot retoryki) i o tym, co pozajęzykowe (res - przedmiot rozważań filozoficznych) może odtąd samodzielnie rozwijać swoje zdolności oraz zainteresowania, mając ciagle przed oczyma ideał wymownej mądrości (i mądrej wymowy), najpełniej ucieleśniony w postaci Cycerona.

W drugiej części listu do opata benedyktynów tynieckich Górski szczegółowo przedstawia okoliczności powstania podręcznika o figurach gramatycznych i retorycznych. Wykłady z retoryki, prowadzone przez wiele lat, utwierdziły humanistę w przekonaniu o potrzebie zebrania w jednej książce przepisów wymowy zaczerpniętych $z$ dzieł najbardziej uznanych jej nauczycieli, z Cyceronem i Kwintylianem na czele. Podczas pracy nad przystępnym wykładem reguł elokucji Górski korzystał ze swoich notatek i komentarzy do wybranych mów i tekstów retorycznych Arpinaty (zwłaszcza dialogu O mówcy), które uzupełniał obszernymi niekiedy wypisami z podręczników współczesnych mu retorów:

Quae quidem praecepta non levem aliquam atque usu protritam rationem eloquendi tradunt, sed ea, quae occultior est et quae extremam eloquentiae manum imponit. Haec autem quae de figuris atque ornamentis quod a multis et veteribus et recentioribus explicata esse usuque frequenti protrita putarem, omnino me aediturum negaveram, ne inutilem laborem post tot tam praestantes scriptores susciperem, neve actum (ut dici solet) agere viderer. Verum cum eorum ipsorum libros, ad quos dicendi studiosos remisserant, diligentius inspexissem, animadverti, me non omnino inutilem laborem suscepturum, non nihilque utilitatis studiosis dicendi allaturum, si eam quoque partem eloquendi more meo atque ea methodo, quam in his praeceptis dicendi explicandis tenere soleo, explicatam in publicum emitterem [Te przepisy uczą nie jakiejś niepoważnej i zniszczonej użyciem sztuki przemawiania, lecz tej, która jest bardziej zawiła i która przykłada do wymowy rękę po raz ostatni. Dotyczy ona zatem figur i ozdób mowy. Uważałem, że została wyłożona przez wielu dawnych i współczesnych autorów i zniszczona częstym użyciem, nie chciałem w ogóle jej przedstawiać, ani podejmować bezużytecznej pracy po tak wielu znakomitych autorach, ani robić tego, co wydawało mi się (jak się zwykło mówić) już zrobione. Kiedy jednak nieco uważniej przejrzałem książki tych autorów, do których odsyła się studentów wymowy, stwierdziłem, że nie podejmę całkiem bezużytecznej pracy i przyniosę studentom wymowy pewien pożytek, jeśli również tę część wymowy, wyłożoną zgodnie z moim zwyczajem i metodą, której trzymałem się zwykle podczas wykładu tych przepisów wymowy, ogłoszę publicznie drukiem]. [k. A8-A8v]

Ukazując znaczenie elokucji w procesie powstawania mowy, Górski posłużył się metaforą pochodzącą z teorii retorycznej Cycerona, który przeprowadził analogię między wymową a malarstwem. Jeśli retoryka jest sztuką malowania słowami, to tropy i wszystkie ozdoby językowe, opisywane i porządkowane na gruncie nauki o formach wysłowienia, przypominaja „, barwy retoryczne” (colores rhetorici) ${ }^{20}$. Według Górskiego elokucja przykłada do wymowy „ostatnią” rękę, czyli wypełnia kolorami stworzony wcześniej rysunek. Kilkoma pociagnięciami pędzla ożywia naszkicowane przedmioty i postacie, które następnie stawia przed oczami słuchaczy (czytelników).

Na wybór opata Łowczowskiego, „najlepiej zasłużonego Mecenasa” i „ojca sztuk wyzwolonych”, na patrona podręcznika Górskiego wpłynęły dwie rzeczy. Pierwszą stanowią liczne zalety ducha i umysłu adresata, do których należą niezwykła łaskawość dla autora, miłość okazywana studentom bonae litterae oraz uczonym

20 Metafora „barw retorycznych” pojawiła się po raz pierwszy w połowie XI w. w tytule traktatu Onulfa ze Spiry (Rhetorici colores, ok. 1050), nauczyciela gramatyki i retoryki w szkole przykatedralnej w Spirze. Zob. J. J. M u r p hy, Rhetoric in the Middle Ages: A History of Rhetorical Theory from St. Augustine to the Renaissance. Berkeley 1974, s. 189-190. - J. C. Li n d e, Die „Rhetorici colores” des Magisters Onulf von Speyer. „Mittellateinisches Jahrbuch” t. 40 (2005). 
wykładającym w Akademii oraz życzliwość dla uczelni, poświadczona wieloma darowiznami i zapisami. Druga - serdeczna gościnność, jakiej opat udzielił humaniście w drugiej połowie 1559 roku, kiedy z powodu szalejącej w Krakowie zarazy zawieszono wykłady w szkołach, a wielu nauczycieli szukało schronienia przed morowym powietrzem poza murami szybko wyludniającego się miasta. Przyjaciel Górskiego i wybitny znawca pism Cycerona, Andrzej Patrycy Nidecki (1522-1587), skorzystał np. z gościny wspomnianego już Myszkowskiego, sekretarza wielkiego koronnego, i spędził ten czas w jego rezydencji w Bieżanowie, gdzie pracował nad edycją fragmentów pism Arpinaty. Po wyjeździe $z$ „opustoszałego Krakowa” (deserta Cracovia) humanista przybył do pobliskiego opactwa benedyktynów w Tyńcu. W świetnie zaopatrzonej bibliotece klasztornej mógł poświęcić się studiom nad retoryką (stylistyka) podziwianego Cycerona i pracy nad podręcznikiem elokucji.

W rozbudowanej narracji o schronieniu przed zarazą w murach klasztoru topos „niepróżnującego próżnowania” (otium negotiosum) przeplata się z benedyktyńskim etosem pracy. Naturalne piękno miejsca (opactwo leży na wapiennym wzgórzu nad Wisła), które stało się dla humanisty bezpieczną przystanią, obudziło w nim na nowo zainteresowanie ozdobami językowymi przydającymi wdzięku mowie:

Et quoniam et tempora ea essent, ut gravioribus studiis occupari non commodum esse videretur et loci ipsius amoenitas et pulchritudo hoc videbatur efflagitare, ut in amoenioribus et venustioribus studiis ea tempore collocarem, statim ea quae ad ornamentis orationis privatim dictare solebam diligentius excolere, multoque copiosius, multo explicatius eam materiam explicare, quam dictando pueris solebamus, coepi. Aestate igitur tota in eo studio consumpta ad finem tandem eius operis perveni, quod in recessu plus laboris habere expertus sum, quam in fronte ostendebat [A ponieważ takie były czasy, że zajmowanie się poważniejszymi studiami zdawało się nieodpowiednie, urok zaś i piękno miejsca zdawały się skłaniać do tego, abym poświęcił się wtedy przyjemniejszym i wdzięczniejszym studiom, zacząłem natychmiast staranniej rozwijać te rzeczy związane z ozdobami mowy, których uczyłem zazwyczaj prywatnie, a także wyjaśniać obszerniej i dokładniej tę materię, niż miałem w zwyczaju podczas nauki chłopców. Kiedy wykorzystałem całe lato na to zajęcie, dotarłem nareszcie do końca tego dzieła; przekonałem się, że wymaga ono więcej pracy w odosobnieniu, niż zdawało się na początku]. [k. Bv-B2]

Zależność, na którą wskazuje Górski, między porządkiem natury a figurami wysłowienia, jest pochodna procesu naturalizacji figuratywności. W przekonaniu humanistów zajmujących się przepisami elokucji formy językowe znane jako tropy i figury retoryczne nie są w żaden sposób sztucznym tworem nauczycieli wymowy, ale stanowią odpowiedź na różnorodność i piękno otaczającego świata. Na gruncie języka naśladują przyrodę $\mathrm{w}$ wielości form, jakie może ona przyjmować. Zwielokrotniając potencjał nazywania rzeczy, figury retoryczne, w których Cyceron widział kwiaty słów i myśli albo światła (klejnoty) mowy, mają sprawiać odbiorcy przyjemność estetyczną.

O podobnych rzeczach pisze Górski w liście do „młodzieńca studiującego” retorykę (zaraza panująca w Krakowie, przerwa w zajęciach akademickich, zalety nowego podręcznika), datowanym na drugą połowę lipca 1560. Wskazuje poza tym na Cycerona jako na mistrza i przewodnika w sztuce tworzenia ozdób retorycznych. Przypominając o swoich trzech książkach poświęconych w całości zagadnieniom elokucji (okresy retoryczne, rodzaje wymowy, figury wysłowienia), proponuje, aby wykładom $z$ retoryki towarzyszyła nauka gramatyki łacińskiej w zakresie frazeologii i syntaksy. Dlatego zaleca swoim uczniom (i czytelnikom) studiowanie podręcznika De emendata structura Latini sermonis (O poprawnej strukturze języka łaciń- 
skiego, 1524), który opracował angielski humanista Thomas Linacre (ok. 1460 $1524)^{21}$. Książka ta cieszyła się dużym zainteresowaniem nauczycieli (świadczą o tym m.in. edycje i przedmowy Melanchtona czy Joachima Camerariusa) oraz uczniów gramatyki w całej wczesnonowożytnej Europie. Stała się również podstawą nauki poprawnej łaciny w Akademii Krakowskiej.

W komentarzu do wieloznacznego terminu „figura” Górski przywołuje wszystkie metaforyczne określenia używane przez Cycerona w mówieniu o formach językowych:

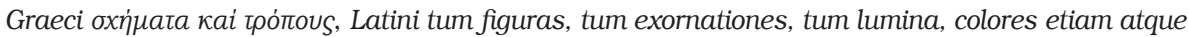
ornamenta orationis appelare solent. Cicero (qui schemata a Graecis quasi gestus orationis dici censet) concinnitatem, formas, conformationes quoque appellavit, omnia ornamenta orationis ea voce complectens. [...] Est autem figura dicendi forma arte aliqua novata et a communi consuetudine dicendi deflexa. [Grecy mówią zwykle o tropach i figurach (охп் аaта каi трórous), a autorzy łacińscy o figurach, szatach, klejnotach, a także barwach i ozdobach mowy. Cyceron, który uważał, że figury były nazywane przez Greków jakby gestami mowy, mówił także o wytworności, formach, postaciach, obejmując tym słowem wszystkie ozdoby mowy. 〈...〉 Figura jest zatem formą wypowiedzi zmienioną dzięki pewnej sztuce i przekształconą względem zwyczajnego sposobu mówienia]. [s. 1]

Każda $z$ wymienionych przez humanistę nazw dzięki swej jawnie metaforycznej postaci daje początek obrazowym narracjom: o różnobarwnych szatach słów, utkanych $\mathrm{z}$ rozmaitych figur wysłowienia, albo o niezwykłych barwach retorycznych, dzięki którym można odmalować również rzeczy niedostępne dla percepcji wzrokowej człowieka.

Uznanie Cycerona za autorytet na gruncie teoretycznie ukierunkowanej elokucji wiązało się jednak z pewnymi problemami interpretacyjnymi, ponieważ rzymski mówca nie przedstawił systematycznego i koherentnego wykładu nauki o figurach retorycznych ${ }^{22}$. Pozostał przy nieco ogólnikowych rozważaniach o stylu i przy wyliczeniu głównych tropów oraz innych form języka, opatrzonych lapidarnym komentarzem i kilkoma przykładami. $Z$ tego powodu Górski posłużył się w definicji figury frazą wyjęta wprost $\mathrm{z}$ dzieła Kwintyliana, o wiele bardziej precyzyjnego w swoim wykładzie (Inst. orat. IX 1, 14) ${ }^{23}$. Wynika $z$ niej, że aby można było dane wyrażenie określić mianem ozdoby retorycznej, musi ono spełniać równocześnie dwa warunki. Po pierwsze, stanowić efekt wyraźnej zmiany (słów, znaczenia), wprowadzonej zgodnie $\mathrm{z}$ odpowiednimi regułami sztuki elokucji. Po drugie, powinno wyróżniać się na tle zwykłego - czyli traktowanego przez użytkowników danego języka jako naturalny, codzienny, powszechny - sposobu mówienia. Uważając zmianę i odkształcenie za istotę figury retorycznej, a jednocześnie celowo nie określając precyzyjnie przedmiotu owych dwóch operacji językowych, zaproponował Górski bardzo szerokie rozumienie tego wieloznacznego pojęcia.

Jeśli przyjmiemy zaproponowaną przez humanistę definicję, to dojdziemy do

Zob. M. Cy t o w s k a, Od Aleksandra do Alwara. Gramatyki łacińskie $w$ Polsce $w$ XVI $w$. Wrocław 1968, s. 83-84. - K. J en s e n, De emendata structura Latini sermonis: The Latin Grammar of Thomas Lincare. „Journal of the Warburg and Courtauld Institutes” t. 49 (1986). 
podobnego wniosku - trop jest tym samym co figura. Oba pojęcia mogą być zatem używane wymiennie:

Etsi autem tropum et schema nonnulli diversa esse volunt, tamen aut idem prorsus sunt, aut admodum tenui discrimine distant; usus certe utriusque idem est, utriusque ea vis est, ut orationem a recta nativaque et simplici significatione cum aliqua virtute atque ornamento dicendi deflectat atque genus dicendi sua sponte fusum in genus conversum, quod totum ab arte petitur, mutet. Guod enim tropum esse volunt, sermonem a naturali ac principali significatione translatum ornandi gratia, figuram vero ac schema arte aliqua novatam (ut diximus) dicendi formam, idem certe verbis solum nonnihil immutatis dicunt; utriusque descriptionis ea vis est, ut ostendat et tropum et schema nihil aliud esse, quam verbi vel sermonis a propria significatione ad aliam, quae illi propria non sit, cum virtute ac ornamento quodam, immutationem [Jeśli nawet niektórzy utrzymują, że trop i figura są czymś odmiennym, to jednak albo są zupełnie tym samym, albo dzieli je niewielka różnica. $Z$ pewnością użycie obu jest takie samo i każde z nich ma taką własność, że odkształca wypowiedź względem właściwego i pierwotnego znaczenia, przydając mowie pewnej wyrazistości i ozdoby, a także zmienia rodzaj wymowy z płynącego swobodnie na przetworzony, który zależy w całości od sztuki. Jeśli bowiem utrzymują, że trop jest wyrażeniem przeniesionym $z$ pierwotnego i właściwego znaczenia w celu ozdobienia mowy, figura zaś i postać jest - jak powiedzieliśmy - formą wypowiedzi zmienioną dzięki pewnej sztuce, to mówią bez wątpienia to samo, tylko za pomocą nieco innych słów. Wyjaśnienie każdego z nich ma taką własność, że wskazuje, iż trop i figura nie są niczym innym, jak zmianą słowa albo wyrażenia $z$ właściwego znaczenia na inne, które nie jest mu właściwe, z pewną wyrazistością i ozdoba]. [s. 1-2]

Twierdzenie Górskiego wymaga kilku słów komentarza. O ile bowiem każdy trop jest niewątpliwie figura (określonym, odpowiednio zmienionym, „odkształconym" zwrotem językowym), o tyle nie każda figura może zostać uznana za wyrażenie tropiczne. Mówiąc nieco inaczej, relacja między tymi pojęciami wyklucza pełną symetryczność i automatyczna przechodniość. Trop to taka figura, której istotę stanowi przeniesienie znaczenia, regulowane przepisami retoryki i motywowane względami estetycznymi. Dzięki wyraźnej zmianie semantycznej, koniecznej do powstania tej formy wysłowienia, o wiele bliżej jej do figur myśli niż słów. Pojawienie się figuratywności prowadzi nieuchronnie do zmiany genologicznej, gdyż przekształca swobodny rodzaj wymowy w artystycznie przetworzony. Albo jeszcze inaczej: zwykły, tzn. pozbawiony ozdób językowych, sposób mówienia przemienia w mowę upiększoną za pomocą licznych tropów i figur. Oba rodzaje, występujące często w obrębie tej samej wypowiedzi oratorskiej, opisał Górski szczegółowo w podręczniku $O$ rodzajach wymowy ${ }^{24}$. Co ciekawe, pierwszy z nich można nazwać (wspomina o tym autor) gramatycznym (mowa jasna, prosta i poprawna), drugi zaś - retorycznym (mowa zasobna w słowa, tropy i figury). Po raz kolejny okazuje się, że figuratywność, domena swobodnych przekształceń językowych, stanowi znak rozpoznawczy retoryki.

Górski wylicza 10 tropów: metafora, synekdocha, metonimia, antonomazja, onomatopeja, katachreza, metalepsa, acyrologia, peryfraza i alegoria przybierajaca niekiedy postać zagadki, przysłowia, ironii, antyfrazy albo hiperboli ${ }^{25}$. Najwięcej uwagi poświęca humanista metaforze, czyli „przeniesieniu słowa $z$ właściwego

25 Zob. s. 26: „Est autem tropus (ut iam diximus) verbi vel sermonis a propria significatione in aliam cum virtute mutatio, cuius genera decem sunt: methaphora, synechdoche, methonimia, anthonomasia, onomathopeia, cathachresis, metalepsis, acyrologia, periphrasis, allegoria, cum his quae eis subiiciuntur formis, de quibus suo loco". 
miejsca (a proprio domicilio) w inne, lecz podobne miejsce" (s. 24). Użyte w tej definicji przez autora wyrażenie „domicilium” 'siedziba, dom, miejsce zamieszkania' jest metaforyczne i wskazuje na rolę konwencji, sprawiającej, że słowa wydają się zadomowione $\mathrm{w}$ języku na stałe. Mają bowiem ustalone znaczenie, które można przenosić tylko pod warunkiem uwzględnienia relacji podobieństwa między denotowanymi przez nie rzeczami. Zgodnie z poglądem Arystotelesa (Poet. 1457 b, 6-33: metafora jako rodzaj podobieństwa), przejętym następnie i rozwiniętym przez Cycerona (De orat. III 39, 157) i Kwintyliana (Inst. orat. VIII 6, 8-9), przenośnia „nie jest niczym innym jak porównaniem skróconym do jednego słowa $z$ powodu zwięzłości, a samo porównanie - metaforą rozwiniętą i jakby rozszerzoną względem swej krótkości"26.

Humanista omawia pięć sposobów tworzenia wyrażeń metaforycznych, opisanych szczegółowo w podręcznikach gramatyki Donata i Diomedesa, przypomnianych przez Erazma z Rotterdamu w dziele De duplici copia rerum ac verborum (O dwojakim zasobie słów i rzeczy, 1512). Pierwszy, najczęściej stosowany, polega na przeniesieniu znaczenia w obrębie frazeologii związanej z relacją: ciało-umysł. Dlatego mówimy: „Widzę, o czym myślisz”, zamiast: „Rozumiem twoje myśli i zamiary”; „trzymać w pamięci” zamiast „pamiętać”; i „zobaczyć” zamiast „poznać”. Drugi sposób to przeniesienie nazwy cech zwierzęcia żyjącego na istotę rozumną (albo odwrotnie), jak np. „szczekać” zamiast „obmawiać”, „pies” zamiast „pochlebca”, „pszczoła” zamiast „osoba pracowita”. Trzeci sposób, bardziej śmiały i odważny, zakłada przemieszczenie znaczeń ze zwierzęcia na coś nieożywionego, jak w słowach Wergiliusza (Aen. XI 368-369): „si tantum pectore robur / concipis” („Jeśli z serca czerpiesz tak wielką siłę”; „robur” oznacza 'twarde drzewo, najczęściej dębowe'). Czwarty sposób wiąże się z przeniesieniem słowa ze zwierzęcia na inne zwierzę, jak we frazie „pasące się pszczoły” (przykład powtórzony za Erazmem). I wreszcie piąty sposób to przesunięcie znaczenia $z$ jednej rzeczy nieożywionej na inną, jak u Cycerona, kiedy mówi on o „burzy republiki”. Każda z wymienionych reguł, techniczna i silnie związana z porządkiem gramatyczno-logicznym, wskazuje kierunek translacji i substytucji semantycznej, które stanowią istotę nie tylko metafory, lecz także każdego innego tropu.

Wśród przyczyn wynalezienia przenośni Górski wymienia - za Cyceronem konieczność (potrzebę) językową oraz przyjemność estetyczną:

Inventa autem est metaphora primum necessitatis causa, deinde celebrata voluptatis et delectationis. Cum enim non essent propria verba, quibus rerum natura consignari posset, homines ingeniosi ad aliena cognata tamen confugerunt eisque tamquam propriis res propria appellatione carentes consignarunt, veluti cum agricolae vites suas turgescere viderent, nec haberent nomina, quibus idipsum exprimerent, gemmare eas dixerunt, idque ipsum quod turgesceret gemmam appellarunt, translato verbo a gemmis, quae sunt lapides preciosi [Metafora została zatem wynaleziona, po pierwsze, z powodu konieczności, a po drugie, $z$ powodu znanej rozkoszy i przyjemności. Kiedy bowiem nie ma właściwych słów, za pomocą których można nazwać rzeczy, pomysłowi ludzie uciekają się do innych, lecz podobnych słów i nazywają nimi, jakby właściwymi, rzeczy, którym brakuje właściwej nazwy. Na przykład, gdy rolnicy widzą, że pędy winnej latorośli nabrzmiewają, a nie mają nazw, którymi mogliby to właśnie wyrazić,

Zob. s. 27-28: „Vultque idem Cicero, metaphoram esse nihil aliud, quam similitudinem contractam ad unum verbum causa brevitatis, quemadmodum similitudinem ipsam, metaphoram explicatam et quasi e suis angustiis evolutam". 
mówią, że są one ozdobione klejnotami, a to, co nabrzmiewa, nazywają klejnotem za pomocą słowa przeniesionego od klejnotów, które są drogocennymi kamieniami]. [s. 27]

Wprowadzona przez Arpinatę metaforę „klejnotów winnej latorośli” (De orat. III 38, 156) skomentował również Kwintylian (Inst. orat. VIII 6, 6-7), pisząc o nie znających reguł retorycznych chłopach, którzy posługuja się przenośniami z konieczności. Inwencja elokucyjna powołuje do istnienia tropy (nie tylko metafory) w odpowiedzi na niewspółmierność między dwiema sferami rzeczywistości: znaczącym (verba) i oznaczanym (res) ${ }^{27}$. W sytuacji ograniczonego zasobu słów wobec potencjalnie nieskończonej liczby rzeczy człowiek jest zmuszony do określania ich za pomocą nowych wyrażeń językowych albo starych, lecz przeniesionych z macierzystego kontekstu zgodnie $z$ logika analogii (podobieństwa) i przepisami retoryki. Suplementacyjną funkcję tropów uzupełniła z czasem, zdaniem Cycerona, estetyczna. Podobnie szata, która miała na początku chronić człowieka przed zimnem, stała się później ozdobą ciała i oznaką sprawowanego urzędu. Przenosząc ten metaforyczny obraz nakreślony przez Arpinatę w sferę rozważań nad elokucją, można powiedzieć, że żadna ozdoba językowa (szata utkana ze słów) nie jest tylko pustym znaczeniowo ornamentem. Wyposażona w nowe (albo tylko odnowione dzięki przeniesieniu w nowy kontekst) znaczenia, staje się często zwornikiem semantycznym całej wypowiedzi.

Ze względu na stopień trudności zrozumienia - metafory dzielą się na śmiałe, wyprowadzone z rzeczy bardzo od siebie oddalonych (wspomniana „burza republiki”), oraz na rozpowszechnione, utworzone na podstawie przedmiotów blisko ze soba związanych (,płonę” zamiast „pragnę”, „dotykam rzeczy” zamiast „rozumiem”, „widzę” zamiast „poznaję"). Górski przypomina również podział przenośni zaproponowany przez Erazma ${ }^{28}$, który wyróżniał metafory przechodnie i zwyczajne, zwane przez Greków akolutami (,woźnica” zamiast „władcy” lub „władca” zamiast „woźnicy” i odwrotnie) oraz nieprzechodnie (określane również jako anakoluty), jak „szczyt” zamiast „wierzchołek góry” (ale nie „wierzchołek” zamiast „głowy”, gdyż słowo „vertex” może oznaczać albo 'czubek głowy', albo 'szczyt góry', „cacumen” zaś tylko 'wierzchołek góry'). Podczas tworzenia metafor powinniśmy wystrzegać się m.in. następujących błędów: niepodobieństwa (jak we frazie z twórczości Enniusza: „ogromne sklepienia niebios”), używania określeń nazbyt od siebie oddalonych (raczej „otchłań dóbr” niż „Charybda dóbr”), brzydoty (,państwo zostało po śmierci Scypiona Afrykańskiego wykastrowane”) oraz nieodpowiedniości wobec rzeczy (,,burza biesiad” albo „biesiada burz”). Katalog tych niedoskonałości utworzył Górski na podstawie uwag Cycerona wypowiedzianych w dialogu $O$ mówcy ustami Krassusa (III 40, 162-166).

Analogicznie postapił humanista, wyjaśniając, dlaczego metafory tak bardzo podobaja się słuchaczom. Także tym razem słowa Arpinaty (De orat. III 40, 160) pomogły autorowi podręcznika powiązać umiejętność wynajdywania obrazowych

27 Zob. Kw in ty li a n, Inst. orat. III 5, 1: „Omnis autem oratio constat aut ex iis, quae significantur, aut ex iis, quae significant, id est rebus et verbis [Każda więc mowa składa się $\mathrm{z}$ tego, co jest oznaczane, i z tego, co oznacza, czyli ze słów i rzeczy]".

28 Desiderius Erasmus Roter od a mus, De duplici copia verborum ac rerum. Lipsiae 1550, ks. 1 , rozdz. 17 , s. 72 . 
przenośni, wywiedzionych z doświadczeń zmysłowych (zwłaszcza wzrokowych), z błyskotliwością umysłu i zręcznością oratorska w prowadzeniu słuchacza po tropach głównego toku myślenia. Mówienie między słowami wiąże się z koniecznością pójścia dłuższą i często okrężną drogą. Wdzięk oraz piękno metafor sprawiają, że odbiorca, oczarowany niecodziennymi przedstawieniami rzeczy, staje się bardziej podatny na perswazję. W wyrażeniach tropicznych (metaforycznych) przyjemność estetyczna łączy się także ze sferą semantyczną (konieczność rozszyfrowania znaczenia). Górski powtarza za rzymskim oratorem: „Żadna figura nie jest piękniejsza w pojedynczych słowach ani żadna nie dodaje takiego blasku mowie jak metafora” 29 .

Zwielokrotnienie przenośni powiązanych ze sobą relacją podobieństwa prowadzi do powstania tropu zwanego alegorią, na co zwracał uwagę zarówno Cyceron, jak i Kwintylian:

quam Cicero ait esse, cum fluxerunt plures continue translationes. Neque enim uno in verbo est translato, sed ex pluribus continuatis connectitur, ut alia plane fiat oratio, quae aliud verbis, aliud sententia demonstrat. Semper enim in eo tropo aliud dicitur, aliud vero intelligendum est. Huius generis est illud Terentii: „Scelesta lupo ovem commisisti”, hoc est adolescenti amore flagranti puellam custodiendam tradidisti tamquam lupo ovem ieiuno. [...] Nihil enim aliud est allegoria, quam continuata methapora. Hoc tamen differt a translatione, quod translatio in uno verbo sit, alegoria vero in pluribus translatis continuatis [Cyceron powiada, że pojawia się ona 〈tj. alegoria〉 wtedy, gdy kilka metafor płynie bez przerwy (Or. 92). Nie znajduje się bowiem w pojedynczym przeniesionym słowie, lecz jest połączeniem kilku następujących po sobie słów, aby powstała zupełnie inna mowa, która coś innego wskazuje słowami, a coś innego znaczeniem. W tym tropie zawsze mówi się coś innego, a coś innego trzeba rozumieć. Do tego rodzaju należą owe słowa Terencjusza: „Nieszczęsna, powierzyłaś owieczkę wilkowi!” (Eun. 832), to znaczy przekazałaś młodzieńcowi płonącemu z pożądania dziewczynę, którąś miała strzec, jak owcę głodnemu wilkowi. Alegoria nie jest bowiem niczym innym niż przedłużoną metaforą. Różni się jednak tym od przenośni, że metafora znajduje się w pojedynczym słowie, alegoria zaś w wielu następujących po sobie metaforach]. [s. 32-33]

Powtórzmy raz jeszcze za Kwintylianem (Inst. orat. VIII 6, 44): alegoria to rozbudowana konstrukcja metaforyczna (metaphora continuata), której znakiem rozpoznawczym jest równoczesne sygnalizowane dwóch sensów: dosłownego (literalnego) i niedosłownego (figuratywnego), odsłanianego w procesie lektury i interpretacji alegorycznej ${ }^{30}$. Co szczególnie interesujące, Górski wyróżnia dwie odmiany alegorii: poetycka i oratorska (retoryczną). Ta pierwsza pojawia się wiele razy w $\mathrm{Bu}$ kolikach Wergiliusza, mistrza mówienia nie wprost i operowania aluzją, oraz w niektórych odach Horacego rozwijajacych konsekwentnie jeden obraz alegoryczny, np. okrętu miotanego przez morskie fale (Carm. I 14) albo roztropnego żeglarza płynącego spokojnie dzięki cnocie przez morze życia (Carm. II 10). Humanista opatruje te dwa przedstawienia poetyckie następującym komentarzem:

In priore ode per navem intelligit Sextum Pompeium bello navali mare infestantem, quem hortatur, ut pacem ab Augusto petat, antequam bellum illi inferatur, in posteriore vitae mediocritatem commendat [W pierwszej pieśni poeta przez okręt rozumie Sekstusa Pompejusza namawiającego do bitwy morskiej,

Zob. s. 32: „Nullus autem modus est florentior in singulis verbis, nec qui plus luminis afferat orationi, quam metaphora".

30 Zob. J. A bra mow ska, Alegoreza i alegoria w dawnej kulturze literackiej. W zb.: Problemy odbioru i odbiorcy. Studia. Red. T. Bujn i cki, J. Sławiński. Wrocław 1977. - T. Michałows k a, Średniowieczna teoria literatury w Polsce. Rekonesans. Wrocław 2007, s. 221-224. 
którego zachęca, aby prosił on u Augusta o pokój, zanim wypowie mu wojnę. W drugiej zaś zaleca umiarkowanie w życiu]. [s. 34]

Alegorie oratorskie obejmują zagadki i przysłowia. Wyrażenia zagadkowe (paraemiae, adagia, proverbia), zwane także alegoriami niejasnymi, pełne są zamierzonej wieloznaczności i dlatego przystoją bardziej poetom niż mówcom (zrozumiałość jest cnotą wysłowienia), nawet jeśli niejasność może sprawiać słuchaczowi przyjemność. Nieco inaczej przedstawia się ta kwestia w przypadku przysłowia, które Górski określa słowami Erazma jako „znane powiedzenie wyróżniające się pewną pomysłową nowością"31, jak w przykładzie zaczerpniętym z komedii Terencjusza (Phorm. 506): „trzymać wilka za uszy” (gdy zarówno zatrzymanie, jak i porzucenie danej rzeczy może okazać się niebezpieczne). Przewodnikiem Górskiego w rozważaniach o przysłowiach pozostaje Erazm $z$ Rotterdamu, autor obszernego zbioru adagiów, systematycznie zresztą powiększanego, który upowszechnił humanistyczną ideę dzielenia się myślami i słowami starożytnych autorów z innymi w duchu przyjaźni ${ }^{32}$ zgodnie $^{2}$ z maksymą, że przyjaciele mają wszystko wspólne.

Trzecią i z pewnością najbardziej wyrazistą odmianą mowy alegorycznej jest ironia, która pojawia się wtedy, gdy „coś innego mamy ukrytego w sercu, a coś innego ujawniamy w języku, sens wypowiedzi okazuje się przeciwny do znaczenia słów" 33 . W rozważaniach nad tą formą wysłowienia Górski korzysta z dzieła Juliusa Rufinianusa De figuris sententiarium et elocutionis (O figurach słów i myśli) ${ }^{34}$. Zawdzięcza temu rzymskiemu retorowi z IV wieku n.e. definicję ironii oraz charakterystykę jej sześciu odmian. Są nimi: chlevasmus (wyśmianie przeciwników i przyznanie im cnót, od których sa jak najdalej, np. o Werresie - „człowiek święty i zapobiegliwy”), charientyzm (,uprzejme szyderstwo”, dowcipne powiedzenie łączone często $z$ mówieniem przykrych rzeczy za pomocą łagodnych słów), asteizm (wytworny żart obmyślony w celu ośmieszenia kogoś), diasyrmus (wychwalanie kogoś albo czegoś z intencją wyśmiania), exutenismus (pogardliwe i lekceważące stwierdzenie) i sarkazm (słowa pełne nienawiści i wrogości, często złośliwy żart). $Z$ tą ostatnia figurą ironii łączą się jeszcze dwie strategie retorycznej złośliwości: szyderstwo (gdy życzymy komuś czegoś złego bądź niepomyślnego) oraz mykteryzm (drwina ujawniona za pomoca intonacji, mimiki albo gestu). W każdej $z$ tych postaci ironii od-

31 Zob. s. 35-36: „Secunda est paraemia, sive adagium, sive proverbium malis dicere, quod definiunt celebre dictum scita quadam novitate insigne, ut illud Terentii lupum auribus teneo, quo significatur res ea quam et retinere et dimittere periculosum est, et illud: quia rete milvio non tenditur, hoc est malis et audacibus hominibus dies apud iudicem non dicitur, de quibus Erasmus in "Chiliadibus" multa gravissime et copiose scribit, a quo praecipue haec pars eruditionis petenda est".

Zob. K. E d e n, Friends Hold All Things in Common: Tradition, Intellectual Property, and the „Adages" of Erasmus. Yale 2008.

33 Zob. s. 36: „Tertia species ironia, quam Rufinianus ait esse, cum aliud in pectore reclusum, aliud in lingua promptum habemus et sententia enunitationis in contrarium a verbis accipitur [...]. Huius rursum species sex numerari volunt: chlevasmum, charientismum, astysmum, diasirmum, exutenismum et sarcasmum".

34 Zob. R. Tu r a s i ew i c z, Problem antycznej ironii. Warszawa-Kraków 1983, s. 57-60. - D. Kn ox, „Ironia”. Medieval and Renaissance Ideas on Irony. Leiden 1989, s. 51-52. Zob. też D. S. Ka u f e r, Ironia, forma interpretacyjna i teoria znaczenia. Przeł. M. B. Fedewicz. W zb.: Ironia. Red. M. Głowińs ki. Gdańsk 2002. 
najdujemy charakterystyczne dla alegorii poróżnienie sensu literalnego wypowiedzi z sensem ukrytym. Mowę ironiczną cechuja bowiem różnica, nierówność oraz niepodobieństwo między słowami a oznaczanymi przez nie rzeczami.

Czwartym rodzajem alegorii jest antyfraza (antiphrasis), zwana niekiedy ironia pojedynczego słowa, ponieważ występuje, kiedy dane wyrażenie trzeba rozumieć przeciwnie do jego znaczenia dosłownego (gdy mówimy o wojnie jako o czymś dobrym albo o Parkach jako o oszczędzajacych ludzi ${ }^{35}$ ). Wreszcie piąta i ostatnia odmianą wyrażenia alegorycznego jest hiperbola, czyli mowa naruszająca w rozmaity sposób kryteria prawdziwości. Orator korzysta z niej często w sztuce amplifikacji i podczas tworzenia pochwały lub nagany. Figura ta pojawia się też wielokrotnie w wystapieniach Cycerona, np. gdy powiada on o Pompejuszu: „prowadził więcej wojen, niż inni o nich czytali, podbił więcej prowincji, niż inni pragnęli posiąść” (De imp. 28). Górski zwraca również uwagę, że niektórzy retorzy zaliczają hiperbolę, opisaną bardzo dokładnie przez Erazma w podręczniku o zasobie słów i rzeczy, do zwykłych ozdób językowych i nie łączą jej z mową alegoryczną ${ }^{36}$.

Jako trzeci trop wymienia humanista metonimię (submutatio, denominatio, transnominatio), która podobnie jak metaforę tworzy przeniesienie znaczenia (podstawienie słowa w miejsce innych słów). W opisie figury denominacji (przemianowania) przywołuje Górski po raz kolejny słowa Cycerona:

Fit autem cum pro verbo proprio subiicitur aliud, quod idem significet, sumptum ex aliqua re consequenti. Gravis est hic tropus in ornatu orationis et saepe sumendus, ex quo genere haec sunt: Martem belli esse communem, Cererem pro frugibus, Liberum appellare pro vino, Neptunum pro mari, curia pro senatu, campum pro comitiis, togam pro pace, arma ac tela pro bello. [Powstaje ona $\langle. .$.$\rangle wtedy, gdy zamiast wła-$ ściwego słowa podstawia się inne, które oznacza to samo, wzięte z jakiejś odpowiedniej rzeczy. „Ten trop jest ważny w upiększaniu mowy i często należy $z$ niego korzystać; 〈...〉 wyrażeniami $z$ tego rodzaju są: "Mars" jako zwyczajne określenie wojny, "Cerera" jako pożywienie, nazywanie wina Liberem, morza Neptunem, kurii senatem, pola komicjami, togi pokojem, oręża i broni wojną” (De orat. III 42, 167)]. [s. 41]

Metonimię tworzy się w praktyce retorycznej na wiele sposobów. Górski wylicza 10 najczęściej stosowanych: wynalazca zamiast wynalazku („Cerera” zamiast „pokarmu”), wynalazek zamiast wynalazcy (Aen. II 297: „wieczny ogień” w odniesieniu do Westy), rzecz zawierająca coś zamiast zawartości (.wypity dzban” zamiast „wypite wino”, „szczęśliwe czasy” zamiast „szczęśliwi ludzie żyjący w tych czasach”), zawartość zamiast rzeczy zawierającej (Aen. II 311 : „najbliższy już płonie Ukalegon” w znaczeniu „najbliższy płonie już dom Ukalegona”), skutek zamiast przyczyny (Horacy, Carm. I 4, 14: „blada śmierć”), wódz zamiast dowodzonych żołnierzy („Hannibal zwyciężony przez Scypiona Afrykańskiego”), autor zamiast dzieła („czytać Wergiliusza”, „porzucić Cycerona”, „poświęcić cały rok na Platona”), znak zamiast oznaczanego (,toga” zamiast „pokoju”, „berło” zamiast „królestwa”), narzędzie zamiast używającego go ludu („sarisa”〈długa włócznia〉 zamiast „Macedończycy”)

Jest to przykład tzw. fałszywej etymologii. Nazwę Parek (Parcae), trzech bogiń losu i przeznaczenia, zwanych również Mojrami (Kloto, Lachesis, Atropos), które przędły nić ludzkiego żywota, można wywieść od czasownika „parco” - 'oszczędzam', 'zachowuję, 'ochraniam'.

36 Zob. s. 41: „Huius tropi praeter caeteros Erasmus vim et naturam copiose explicavit. Non desunt quidam, qui hyperbolem removeant ab allegoria et per se tropum esse velint. Nonnulli inter exornationes rhetoricas eam collocarunt". 
i przymioty albo wady zamiast ludzi, których one dotyczą („cnota sprawiedliwości” zamiast „człowiek sprawiedliwy”).

Z metonimia jako denominacją retoryczną łączy się, zdaniem Górskiego, synekdocha ${ }^{37}$. Jest ona tropem, w którym przeniesienie znaczenia odbywa się w obrębie kategorii: część-całość oraz jedność-wielość (De orat. III 42, 168). Podaną przez Cycerona listę sposobów tworzenia synekdochy humanista uzupełnia o nowe pary pojęć: rodzaj-gatunek (Horacy, Carm. III 9, 23: „i bardziej wzburzony niż Adriatyk”), materia - przedmiot z niej zrobiony (,wydobył żelazo” zamiast „wydobył miecz”), poprzednik-następnik (Liwiusz, Ab Urb. II 20, 2: „spiąc konia ostrogami”). Synekdocha nie ogranicza się w ten sposób do figury opartej na rozumieniu części jako całości (albo odwrotnie), ale obejmuje wymianę znaczeń, którą regulują kategorie logiczne powiązane ze sobą semantycznie. Arbitralność tropu, pochodna względem arbitralności znaku językowego, ulega osłabieniu za pomocą motywacji retorycznej (reguły przenoszenia znaczeń).

Wiele podobieństw do metonimii i synekdochy wykazuje antonomazja (praenominatio), która polega na zastąpieniu właściwej nazwy danej rzeczy innym słowem (Aen. I 65: „ojciec bogów i władca ludzi” zamiast „Jowisz”, „zdobywca Kartaginy” zamiast „Scypion Afrykański”). Jest to figura dotycząca - jak zauważa Górski - „nie tyle słów, ile nazw”. Powinno się określać ją mianem figury osób (figura personarum), ponieważ „właściwą nazwę osoby przenosi się [w tym przypadku] w inne miejsce"38. Istnieje wiele sposobów tworzenia antonomazji: za pomocą wyrażenia patronimicznego („Pelida” zamiast „Achilles”, „Atryda” zamiast „Agamemnon”), przywołania miejsca („Cytherea” zamiast „Wenus”, „Cyntyjczyk” zamiast „Apollo”), epitetu („mąż pobożny” zamiast „Eneasz”), słowa wskazującego dziedzinę sztuki, godność albo urząd („Filozof” zamiast „Arystoteles”, „Apostoł” zamiast „,św. Paweł”, „Poeta” zamiast „Wergiliusz”), określenia cechy poprzez przywołanie konkretnej postaci („Cyceron” zamiast „wymowny”, „Neron” zamiast „okrutny”) lub nazwy narodu („Kreteńczyk” zamiast „kłamca”, „Scyta” zamiast „nieludzko okrutny”).

Tropem, któremu Górski poświęca dużo uwagi, jest onomatopeja (nominatio). Mówca sięga po tę figurę zawsze wtedy, gdy za pomocą instrumentalizacji głoskowej naśladuje dźwięki. Ze względu na kryterium semantyczne humanista wyróżnia dwa rodzaje wyrazów dźwiękonaśladowczych. Pierwszy obejmuje frazy oparte wyłącznie na imitacji dźwiękowej, które nie mają samodzielnego znaczenia (odgłosy radości - „ha, ha”, „he, he”; albo smutku - „heu, heu”). Drugi zawiera słowa charakteryzujące się dodatkowo warstwą brzmieniową (neologizm Cycerona „sullaturit” - 'postępować tak okrutnie jak Sulla'39). Górski przywołuje poglądy Arystotelesa na temat onomatopei - określał on tym pojęciem wszystkie nowe i tworzone w rozmaity sposób słowa. Autor podręcznika zwraca uwagę, że takie słowa, jak „gramatyka”, „retoryka” $i$,dialektyka” wraz z ich terminami technicznymi (np. nazwami tropów i figur retorycznych) zostały zapożyczone $\mathrm{z}$ greki. Wspomina również o wyrażeniach

Zob. T. To d or ov, Synekdochy. Przeł. G. B orkow s ka. „Pamiętnik Literacki” 1986, z. 4.

Zob. s. 44: „Haec autem figura non verborum, sed nominium est, praeterea figura personarum propria, cum scilicet nomen proprium personae alterius loco ponitur. Unde et nomen antonomasiae deductum".

Wszystkie podane przykłady pochodzą z podręcznika Kwintylia na (Inst. orat. VIII 6, 31). 
upowszechnionych w języku łacińskim dzięki chrześcijaństwu („chrzest”, „biskup”). Utożsamiając onomatopeję $\mathrm{z}$ tworzeniem nowych nazw (fictio nominis), Górski nie ogranicza jej do naśladowania dźwięków, ale wpisuje ją w szerszy kontekst retorycznej multiplikacji słów i znaczeń.

Wśród modyfikacji słów (modificationes verborum), które opierają się na substytucji semantycznej, szczególne miejsce zajmuje metalepsa ${ }^{40}$, używana częściej przez poetów niż przez mówców i uważana niekiedy za odmianę metonimii. W praktyce językowej przyjmuje postać stopnia pośredniego między słowem a oznaczaną rzeczą (między językiem a umysłem) ${ }^{41}$, jak np. wtedy, gdy Wergiliusz powiada (Aen. I 60): „wszechmogący ojciec ukrył ich w ciemnych jaskiniach”. Tę frazę objaśnia humanista następująco: „czarny” zamiast „mroczny”, „mroczny” zamiast „niejasny”, „niejasny” zamiast „ciemny”. Metalepsa umożliwia zatem wykorzystanie różnych odcieni semantycznych słowa w celu stworzenia nowej relacji oznaczania.

Podobieństwem do metafory wyróżnia się katachreza, uznawana za rodzaj nadużycia semantycznego (abusio). Pojawia się wtedy, gdy przenosimy słowo z jednej rzeczy na inną rzecz, używając przy tym języka niewłaściwie (niepoprawnie). Retoryka dopuszcza ten błąd z punktu widzenia reguł poprawności gramatycznej na zasadzie wyjątku, zwanego katachreza. Dlatego gdy Eneasz powiada na uczcie Dydony (Aen. II 15-16), że Grecy „wybudowali konia dzięki boskiej sztuce Pallady”, używa słowa „wybudować” w nowym, znacznie szerszym kontekście. Poszukując różnic miedzy katachrezą a metaforą, Górski omawia krytycznie stwierdzenie Kwintyliana (Inst. orat. VIII 2, 6), że trop nadużycia pojawia się najczęściej w sytuacji braku odpowiedniej nazwy. Humanista przypomina, iż w analogicznych okolicznościach sięgamy również po metaforę. Podobieństwo jednak między oznaczanymi rzeczami jest w przypadku katachrezy o wiele bardziej arbitralne. Dzięki temu motywacja między słowem a przedmiotem jego odniesienia ulega osłabieniu. Jeśli każdy trop stanowi rodzaj nadużycia semantycznego, to katachreza, podobnie jak metafora, opisuje mechanizm działania całej figuratywności.

$Z$ naruszeniem poprawności gramatyczno-logicznej mamy do czynienia również wtedy, gdy używamy wyrazów „niewłaściwie odnoszacych się do rzeczy”42. Juwenalis wspomina np. o „oczekiwaniu na czterodniową febrę” (Sat. IV 57), zaburzając $\mathrm{w}$ ten sposób porządek słów usankcjonowany normami gramatyki. Zgodnie z przyjętym zwyczajem językowym mówimy bowiem o oczekiwaniu na coś dobrego, a także o obawianiu się czegoś złego. Trop ten nosi nazwę „acyrologia” i rzadko pojawia się w wystąpieniach mówców. Najczęściej towarzyszy innym figurom, takim jak correctio (poprawienie samego siebie) albo praemunitio (uczynienie zastrzeżenia). Dzięki figurom opartym na celowym zaburzeniu norm gramatyki wyrazy zwracają na siebie uwagę słuchacza (czytelnika), który rozpoznaje w nich rozmyślnie popeł-

Zob. B. C u m ming s, „Metalepsis”: The Boundaries of Metaphor. W zb.: Renaissance Figures of Speech. - G. G e n e t t e, Métalepse. De la figure à la fiction. Paris 2004, s. 10-20. - T. S w o b o d a, Zakrzywienie przestrzeni reprezentacji. Parę słów o metalepsie. „Teksty Drugie” 2005, nr 5.

41 Zob. s. 49: „Fit autem per denominationem, cum res diversae quasi gradatim alia ex alia cognoscutur, ita ut verbum ipsum (quo tamen non dicitur) ex homonimia viam muniat tamquam medius quidam gradus inter id quod dicitur et (ut ita dicam) inter linguam et intellectum".

42 Zob. s. 52: „Breviter: acyrologia est, cum verba male rebus aptantur. Oratores acyrologias fugiunt, quod si aliquando uti eis contingat hoc tropo correctionem vel praemunitionem addunt". 
niony błąd. Może on być jednak źródłem komizmu werbalnego lub dowodem pomysłowości oratora.

Ostatnim z tropów, które wylicza i opisuje Górski, jest peryfraza (circuitio). Polega ona na świadomym pominięciu właściwego słowa i wprowadzeniu w jego miejsce wyrażeń opisujacych dany przedmiot. Jeśli mówienie oznacza na ogół nazywanie rzeczy po imieniu, to mowa retoryczna zakłada mnożenie słów i wynajdowanie nowych określeń. Z tego powodu peryfraza jest jedną z kluczowych figur amplifikacji, która powiększa materię językową oratorskiego wystąpienia. Dlatego Horacy, zamiast powiedzieć „Homer”, posługuje się określeniem „poeta wojny trojańskiej” (Ep. I 2, 1). Podobnie czyni, zdaniem Górskiego, Wergiliusz w inwokacji Eneidy, w której nie nazywa wprost ani głównego bohatera eposu (słynny hendiadys „mąż zbrojny”), ani miejsca, do którego heros przybył, lecz mnoży obrazowe peryfrazy. Od antonomazji ów trop różni się tym, że obejmuje znacznie więcej słów. Wyrażenia peryfrastyczne tworzy się w trojaki sposób: za pomocą etymologii (,sztuka rozprawiania” zamiast „dialektyka”, „miłośnik mądrości” zamiast „filozof”), definicji („sztuka dobrego mówienia” zamiast „retoryka”, „Zwierzę rozumne” zamiast „człowiek”, „wieczna część człowieka” zamiast „dusza”) oraz wyjaśnienia znaczenia, gdy opisujemy cechy i właściwości kogoś albo czegoś („obrońca przyjemności” zamiast „Epikur”, ,poeta z Mantui” zamiast „Wergiliusz”, „przywódca stoików” zamiast „Zenon z Kition”).

W wykładzie nauki o 10 tropach Górski podąża za Cyceronem, uzupełniając opis poszczególnych form tropicznych o uwagi Kwintyliana i Rufinianusa (charakterystyka ironii oraz jej sześciu odmian), a także Linacre’a i Erazma z Rotterdamu (rodzaje metafory i alegorii). Konieczność tych uzupełnien, które sprowadzają się najczęściej do przywołania definicji danego tropu albo jego przykładów, wynika $\mathrm{z}$ oszczędności wywodów Arpinaty na temat figur retorycznych. Aby jednak objąć jego autorytetem całość nauki o elokucji, Górski podaje liczne przykłady tropów zaczerpnięte $\mathrm{z}$ mów Cycerona.

Tropologia humanisty nie ma charakteru spekulatywnego. Służy przede wszystkim przystępnemu wykładowi reguł tworzenia różnych form tropicznych. Jeśli autor rozważa jakiekolwiek zagadnienia teoretyczne, dotyczące głównie problemu granicy między poszczególnymi tropami (np. metaforą i alegorią czy metonimią i metalepsa), to wpisuje je zawsze w kontekst praktycznej nauki pięknego przemawiania. Wobec szeroko zakrojonego programu owocnego - jak metaforycznie mawiali humaniści - nauczania retoryki (stylistyki) Cycerona wszelkie pytania o skomplikowany mechanizm tworzenia i zwielokrotniania nowych znaczeń musiały zostać zawieszone. Wiedział o tym również Adrianus Romanus, gdy prosił Brożka o odnalezienie podręcznika Górskiego, z którego Jakub van Roomen, syn matematyka, miał poznawać figury słów i myśli.

Abstract

WOJCIECH RYCZEK Jagiellonian University, Cracow

RENAISSANCE THEORIES OF FIGURATIVITY (II): JAKUB GÓRSKI

The main aim of the article is a description of the study of tropes set forth by Jakub Górski (1525-1585) in his handbook De figuris tum grammaticis, tum rhetoricis (1560). A reconstruction of the humanist's 
views on the functions of eloquence identified mainly with elocution allows to account for the relationships between rhetoric and dialectic (and in broader sense also with philosophy). An analysis of two key terms in the dictionary of forms of expression (figure, trope) provides for sketching the main determinants of Górski's idea of rhetoric as of an art of amplification and figurativity. Such an analysis is at the same time an introduction to a description of 10 tropes with their numerous types (allegory, irony). Górski's handbook, which brings the basic pieces of information on rhetorical tropes and figures, offers a powerful image of rhetorics teaching at The Cracow Academy in the second part of the $16^{\text {th }}$ century. 